\title{
MODERNIZATION OF PROFESSIONAL TRAINING OF FUTURE SPECIALISTS IN HOTEL AND RESTAURANT BUSINESS
}

\section{Burak V. H.}

\section{INTRODUCTION}

The purpose of professional education is to form qualified human resources to meet the requirements of society, world and domestic labor markets, to create conditions for acquiring knowledge, skills, abilities and competencies in the field of person's professional activity throughout life according to his/her vocation, interests and abilities. However, in modern professional education there are often differences between outdated trends and modern requirements for specialists able to work in the current rapidly changing environment, which ultimately leads to the need to organize and implement additional training of graduates directly in the workplace.

In terms of innovative development of service enterprises there is a need for continuous modernization of the content of professional and practical training of future hotel and restaurant specialists, which involves updating content and curricula, reviewing the ratio of theoretical and practical knowledge according to the needs of employers (stakeholders). As future professionals need recognition of the competencies formed in educational institutions by employers or educational institutions, so they choose such providers of education and training who can provide and recognize the relevant qualifications.

Ukrainian legislation in the field of professional education is based on the National Doctrine of Education Development of Ukraine in the XXI century, as well as regulations of the Ministry of Education and Science of Ukraine, such as: Laws of Ukraine "On Education", "On Higher Education", "On Professional Higher Education", "On professional education ", the Concept of implementation of state policy in the field of professional (vocational-technical) education", Modern professional (vocational-technical) education "for the period up to 2027, etc.

Among the main areas of scientists' research on training of future specialists in hotel and restaurant business in institutions of higher professional education it should be noted: formation of key professional competencies; conceptual approaches and models of training; formation 
of professional, informational and culture of professional communication; use of innovative technologies; pedagogical conditions for formation of readiness for professional activity in future specialists in hotel and restaurant business, etc.

The problem of this process should include: quality of organization and methods of educational process, lack of interaction between enterprises and educational establishments; quality of professional activity of specialists, readiness and ability to perform professional functions in the workplace in the conditions of real production; weak methodological differentiation in training of managers and specialists; lack of material and technical base with specialized laboratories to ensure proper practical training of applicants for educational services; low interest in personal development and advanced training due to lack of motivation and false self-esteem, etc.

Modern economic conditions in 2020 are considered to be the beginning of the latest "milestone" for societies, as planetary society was forced to accept demands of the COVID-19 pandemic, which along with globalization, demographic, technological, political, economic and institutional factors created a renewed socio-economic reality and epidemiological (quarantine) factor continues to completely change the world of activity and professional employment of people.

Currently, the real challenges for Ukrainian education are its quality, socio-economic problems, outflow of human capital, lack of funding due to budgetary constraints and military action in the east of the country, etc. It is necessary to provide educational establishments with appropriate technical equipment and staffing to create and maintain the site and network security, enable organization of free access to jobs, digital competence of teachers, systematic updating of teaching and methodological materials, formation and development of information culture of all participants of educational process.

\section{Theoretical and methodological analysis of experience in training of future specialists in hotel and restaurant business}

Higher professional education is the most important socio-state institution for training of young generation, able to solve future professional problems in a particular field of human activity, provided with a high level of integrated skills and ability to deepen them continuously. Therefore, the issue of research of the peculiarities of professional training of future specialists in hotel and restaurant business in modern economic conditions is actualized. 
A service sector is closely linked to various sectors of economy and social development, and is therefore undergoing radical changes. Thus, scientists A. Kolot and O. Herasymenko summarized the data related to the negative impact of restrictive (quarantine) measures on economic performance in terms of individual industries (subsectors). Researchers claim that hotel and restaurant business has the greatest negative impact among the spheres of economic activity: negative share of the sector in GDP is $-82 \%$, in employment $-64 \%$, in taxes $-82 \%$, share of small business in state ownership is $60 \%$. Despite the fact that the share of hotel and restaurant business in Ukrainian economy is insignificant, a large share of small enterprises is concentrated here ${ }^{1}$. These economic conditions and the current state of the service sector affect organization and implementation of the educational process for specialist training.

The phenomenon of "Industry 4.0", which is based on four groups of technologies that can most influence business and life of people: cognitive technologies; cloud technologies; the Internet of Things and big data, actively influences the service sector. "Industry 4.0» is associated with new technologies and manufacturing models in industry, production automation, data and technology exchange in a single selfregulatory system with minimal or no human intervention in the production process, including block chain, cryptocurrency, big data, information networks. Cyber systems, platforms and much more, which radically change forms of life, motivational guidelines, values. Therefore, the latest ideas will provide new opportunities for training of a modern specialist in hotel and restaurant business, ensuring competitiveness at regional, Ukrainian, European and global levels.

These economic conditions and current state of the service sector affect the organization and implementation of the educational process for specialist training.

Thus, according to M. Babeshko, the universal model of professional training of future specialists in hotel and restaurant business should contain three blocks, each of which as a component includes a number of competencies: Block 1 - Foundation (platform), which is represented by personal competencies (interpersonal skills, integrity, professionalism, initiative, adaptability and flexibility, lifelong learning); Block 2 Connection with the hospitality industry, represented by academic (reading, writing, science and technology, basics of computer work,

\footnotetext{
Колот А., Герасименко О. Сфера праці в умовах глобальної соціоекономічної реальності 2020: виклики для України. URL: http://library.fes.de/pdf-files/bueros/ukraine/16344.pdf
} 
communication, critical and analytical thinking) and professional (collaboration, client Focus, planning and organization, creative thinking, problem solving and decision making, work with the latest technologies, planning and coordination, business Basis) competencies; Block 3 Specialization "Hotel and restaurant business" includes inter-industry (principles and concepts, operations and procedures, security and safety, marketing and sales of hotel and restaurant services, quality assurance and control, availability) and industry (organization of hotel services, marketing and management in hotel and restaurant industry, touring, rest and recreation, meetings, events and exhibitions) competencies. Among the limitations of modern training of future specialists in hotel and restaurant business, the scientist says insufficient interaction of educational institutions with hoteliers, short production practices, inadequate level of foreign language skills, partial adaptation of educational programs to business requirements due to long-term higher education reforms, lack of professional standards for service sector, etc ${ }^{2}$.

Scientist and practitioner V. Zinchenko stuied the peculiarities of tourism and hotel training in the context of Ukraine's European integration and increasing competitiveness of the tourism industry and the study made it possible for him to determine the components of the model of the above specialist. The researcher claims that the first is a personal competence (axiological, personal, informational, ecological, valeological), the second is a professional competence (social, communicative, organizational, exploratory, animation, auto competence). However, professional competence of a specialist in tourism and hotel and restaurant business is based on professionally important qualities: memory, creative thinking, reflection, self-discipline, concentration, accuracy and punctuality, emotional stability, curiosity, observation, attentiveness, openness, contact. Possession of psychophysiological properties: reflectivity, flexibility, abstraction, verbalization, emotional stability - will contribute to realization of a future specialist in professional activities ${ }^{3}$.

Researchers N. Kudla, H. Mandro, D. Moshura emphasize the humanistic (spiritual) content of training of specialists in hotel and

2 Бабешко М.С. Універсальна модель професійної підготовки майбутніх фахівців готельно-ресторанної індустрії. Педагогіка формування творчої особистості у вищій і загальноосвітній школах. 2017. Вип. 53 (106). С. 63-70.

3 Зінченко В. А. Особливості підготовки кадрів туризму і готельної справи в умовах євроінтеграції України та підвищення конкурентності туристичної галузі. Проблеми освіти. 2017. Вип. III (67). С. 241-259. 
restaurant business, in particular, realization in the profession, in their opinion, is connected with necessary psychophysiological properties: interest in content, orientation on universal values, orientation of the profession for the benefit of others; desire to penetrate into modern humanistic orientations; desire to stay in the profession; motivation to achieve high levels of activity; desire to improve as a professional, formation of skills of creative self-realization in business, professional position and culture of behavior ${ }^{4}$.

Researcher A. Vindiuk points to the renewal of educational programs in terms of the need to significantly increase hours for practical training, in his opinion the content of practice-oriented training of future specialists in tourism in higher educational institutions includes: theoretical component (lecture, seminar, independent work, individual activity, course and diploma design, work with information on tourism); practical component (practical and seminar works, game and active professionally oriented forms and methods of training, educational and industrial practice, internships, implementation of tourist projects in groups with the involvement of teachers of higher educational establishments and tourism industry specialists, using possibilities of practice and internships at enterprises $)^{5}$.

Scientist T. Ponochovna-Rysak actualizes the influence of today's socio-economic conditions on the definition of such a set of professional knowledge and skills, business skills of future specialists in hotel and restaurant business, which would allow them to solve atypical problems, use economic thinking, leadership and entrepreneurial skills. According to the researcher, the above requirements of an individual, society and the state can be realized through integration in the educational process of scientific and innovative activities of students through the implementation of a set of creative works and activities. He considers fundamental education and thorough training related to organizational and managerial, economic, commercial, investment and research

${ }^{4}$ Кудла Н.С., Мандро Х.М., Мошура Д.А. Ринкові вимоги до підготовки фахівців готельно-ресторанної сфери. Матеріали I Міжнародної науковопрактичної конференції «Інновації, тренди та перспективи індустрії гостинності» (м. Львів, 12 грудня 2019 р.). Львів: ЛТЕУ, 2019. 192 с. С. $135-138$.

5 Віндюк А.В. Особливості практико-орієнтованого змісту професійної підготовки майбутніх фахівців із туризмознавства в закладах вищої освіти. Вісник Запорізького національного університету. Педагогічні науки. 2017. № 2. C. 98-103. 
activities in the field of restaurant, hotel and exhibition activities to be important $^{6}$.

To overcome a number of contradictions of modern domestic economic development, in particular between the growing demands of employers to the level of professional competence of future professionals and undeveloped theoretical foundations of their training, objective requirements of the labor market in quality modernized training and inconsistency of methodological bases to provide effectiveness of the educational process, L. Korotkova proposes to use the experience of creating and operating of an educational and industrial cluster, whose activities are based on integration of the interests of public authorities (at all levels), industry, non-government organizations, professional associations, scientific and educational sectors with the implementation of goals: strategic (professional competence with consideration to characteristics of post-industrial society), tactical (getting modern theoretical knowledge, specialized practical skills and education of professionally significant qualities), operational (exhaustiveness of strategic and tactical goals specifying integrated tasks). Substantiated pedagogical system, according to the researcher, includes a set of hierarchically subordinated components: target (definition of purposes and tasks for realization of the social order); semantic (content of subjects of general professional, professional-theoretical and professional-practical training); organizational (finding and producing suitable pedagogical conditions, use of appropriate organizational forms); procedural (interrelated teaching methods and tools); resultevaluation (control, analysis and adjustment of the educational process). The conditions for providing qualitative professional training of future specialists in the service sector using the capabilities of the educational and production cluster are: positive motivation to use modern production technologies; modernization of the content of special training of future specialists in service sector, based on the competence approach; introduction of innovative educational technologies; use of integrative educational and methodical complex of professional training ${ }^{7}$.

6 Поночовна-Рисак Т.М. Проблеми професійної підготовки майбутніх фахівців готельно-ресторанної справи. Педагогіка формування творчої особистості у вищій і загальноосвітній школах. 2019. № 62. Т. 1. С. 66-69.

7 Короткова Л.І. Структура педагогічної системи професійної підготовки майбутніх фахівців сфери послуг в умовах освітньо-виробничого кластера. Colloquium-journal. 2020. № 25 (77). URL: https://cyberleninka.ru/article/n/ struktura-pedagogichnoyi-sistemi-profesiynoyi-pidgotovki-maybutnih-fahivtsivsferi-poslug-v-umovah-osvitno-virobnichogo-klastera. 
Complexity and integration of the modern content of education, according to L. Savchenko, are ensured by the appropriate methodological principles of training of future specialists, which are presented in theoretical terms by epistemological, humanistic approaches, continuousness, integrity, consistency; in practical dimension - activity, axiological, systemic, competence approaches. In modern economic conditions with continuous changes in science, education, society, the priority manifestations of professional education of future specialists in hotel and restaurant business of computer graphics, professional mobility, information and communication technologies, the introduction of which facilitates the rapid transfer of knowledge and accumulated technological and social human experience are integral use. Future professionals need high quality education, achievement of material well-being, implementation of an individual educational trajectory in the paradigm of lifelong learning, career growth in the profession ${ }^{8}$.

In modern restrictive and quarantine realities of hotel and restaurant business, institutions of this sector of the economy are in a tough competitive environment, create innovative products, provide unique services, using creative potential of employees. Therefore, in the process of training of future specialists in service sector, scientists V. Sopiga and T. Soroka think, it is necessary to take into account the following current trends in hotel and restaurant enterprises: introduction of information technology in the service process, including the use of interactive (electronic) menu, online ordering or by means of special terminals directly in hotel or restaurant enterprises; distribution of healthy fast food (quality street food); development of food trucks ("cafe on wheels"); popularization of craft drinks; use of food 3d printers; introduction of web monitoring systems in employees' activities; mixing different styles and concepts in restaurant business; improving customer safety and protection of employees through automated comprehensive protection systems ${ }^{9}$.

Scientists V. Radkevych, S. Kravets, A. Kozak point to the important place of the hospitality industry (restaurant industry) in the

${ }^{8}$ Савченко Л. Зміст професійної підготовки фахівців сфери обслуговування. Професіоналізм педагога: теоретичні й методичні аспекти. 2019. Вип. 11. C. $72-80$.

9 Сопіга В.Б., Сорока Т.П. Тенденції розвитку готельно-ресторанних підприємств як фактор впливу на підготовку майбутніх фахівців сфери обслуговування. Вісник КрНУ імені Михайла Остроградського. 2019. Вип. 2 (115). С. 36-41. 
implementation of socio-economic tasks of the state, confirming the growing trend of competition between restaurant industry establishments, which in turn is associated with increasing requirements for the quality of training of future specialists capable of meeting the needs of service consumers and stakeholders at the level of standards adopted in the service sector. The prepared map of assessment of the levels of professional competence contains key competencies (motivation for future professional activity and mastering the profession; ability to interact communicatively; empathy; desire for self-education, mastery of innovative technologies; professional ethics and etiquette; tolerance and politeness, multiculturalism; initiative; responsibility; action and independent decision-making in production situations, ability to work in a team, emotional management, skills of professional mobility, development of lifelong learning skills, etc). Nowadays, taking into account the needs of high-tech production in modern economic conditions, the society places new demands on future specialists in hotel and restaurant business to provide advice on building a professional career; development of abilities to work, retrain and perfect yourselves in accordance with the needs of modern globalized world of work. Scientists confirm the growth in the process of training of future specialists in hotel and restaurant business role along with hard (special, professionally-oriented) soft skills (important for employment), among which are: time management, collaboration (teamwork), creativity, adaptability and flexibility, self-organization, initiative, entrepreneurship, critical thinking, evaluation and analysis of information, responsibility, etc. However, today, in the restrictive quarantine conditions of the COVID-19 pandemic, such soft skills as stress resistance, ability to overcome personal and social difficulties, and health preservation are being actualized. In the context of modern ecological problems of mankind, the skills of ensuring the sustainable development of society through the introduction of resource and energy efficiency, preservation and protection of the environment, etc. are also becoming relevant ${ }^{10}$.

In the context of our study, we should first consider the definition of "training of future specialists in hotel and restaurant business", by which we mean «an organized, continuous, purposeful process of formation and development of professional competencies required for professional

${ }^{10}$ Радкевич В. О., Кравець С. Г., Козак А. Р. Ключові компетентності (м'які навички) майбутніх фахівців індустрії гостинності. Colloquium-journal. 2020. № 15 (67). URL: https://cyberleninka.ru/article/n/klyuchovi-kompetentnosti-m-yakinavichki-maybutnih-fahivtsiv-industriyi-gostinnosti. 
activities, which is performed in the educational establishments of different forms of ownership, aimed at obtaining qualifications by future specialists in accordance with the educational and professional programs of educational levels "bachelor" and "master" specialty 241 "Hotel and restaurant business", which will serve to ensure successful performance of duties, competitiveness and professional mobility in service sector".

The basis of interdisciplinary multidisciplinary training of specialists in service sector are the Standards of Higher Education of Ukraine for the first (bachelor's) and second (master's) levels of higher education in the field of knowledge 24 "Service sector", specialty 241 "Hotel and restaurant business".

Training of these specialists is a combination of theory (educational and cognitive activities in higher educational establishments) with practice (laboratory classes and practical training in the work place: acquaintance with the material and technical base of hotel and restaurant complexes, management structure, rules of use and internal regulations of the enterprise) etc. It is important to use modern methods and forms during the educational process for further organization of production activities of the enterprise, operating procedure of various services, management information system in accordance with modern market methods and forms of management in hotel and restaurant industry, making independent decisions in solving specific production situations. Formation of skills of work with modern information technologies in the field of hotel and restaurant business is actual.

Analysis of modern pedagogical literature on training of future specialists in hotel and restaurant industry made it possible to formulate a definition of "hotel and restaurant business" as a qualified, competitive, socially mobile specialist-organizer of specific professional activities related to planning, organization of service and production technological activity of hotel and restaurant business entities, adjustment and improvement of technological operations, guaranteeing a high level of product quality, able to provide a high level of services and comfort, to meet a variety of household, economic and cultural needs. In addition to mastering integrated, general and professional competencies, ways to ensure the appropriate level of quality of products and services in hotels and restaurants of various types, these professionals need to understand the methods, techniques and information bases of technology for further professional activities and scientific careers in the field of hotel and restaurant business in order to implement his own concept of life success. 
Given the above analysis, the term "competence of future professionals in hotel and restaurant business" will be interpreted as a multi-component dynamic combination, represented by knowledge, skills, abilities, ways of thinking, views, values, other personal qualities, implemented at the levels of higher education, branch of knowledge 24 "Service sector", specialty 241 "Hotel and restaurant business", forms of education, which is a complex of integrated, general ("soft" skills) and special ("hard", professional, subject skills) competencies and determines the ability of a student to successfully socialize, conduct professional and / or further educational activity, independently and purposefully individually increase professional competence, build a career and form own concept of life success.

The term "readiness of the future hotel and restaurant specialist for professional activities" is analyzed as a result of training at the institutions of professional pre-higher and higher education of various forms of ownership, possession of customers of educational services professionally oriented knowledge, skills, abilities and competencies, which set up a correspondence with the demands on providing various services to clients of hotel and restaurant enterprises; is based on conscious abilities to the chosen profession, reflection, provides the ability to research and innovation, continuous self-development and selfeducation throughout life.

World stakeholders, heads of enterprises in the field of tourism, hotel and restaurant business, among the top signs of readiness of future specialists in the service sector name: presence of positive attitude, abilities to the chosen profession and important qualities; general and special professional knowledge, skills, abilities, competencies; formation of skills of team and independent creative work; acquiring the ability to use the methods of scientific knowledge and carry out innovative activities; readiness for continuous self-development and self-education, ability to reflect; formation of appropriate psychological qualities of a personality, character traits that determine the special style of professional activity of specialists in service sector. In addition, we consider it appropriate to renovate them through the updating of skills such as active learning and learning strategies (ability to learn actively, effectively); stress resistance and flexibility (working with mistakes, as well as in situations of uncertainty), as dynamic changes, uncertainty and necessity, readiness for continuous retraining, according to world futurists, will be a mandatory feature of the future. The application of the above innovations takes place in the process of modernization of modern standardized requirements for training of these specialists, formation of 
integrated competence, hard and soft cross-cutting skills in students and implementation of the concept of lifelong learning.

\section{Modernization of professional training of future specialists in hotel and restaurant business in the context of globalization changes and reform of the education sector in Ukraine}

Today's globalization and socio-economic processes determine the problems of professional training of future specialists as for formation of their readiness to carry out production activities and development of professionalism in lifelong learning.

Modern reform of higher professional education in service sector is intended to change the status of a specialist, determine the list of continuously updated competencies and qualification functions, establish requirements for professional training and level of professionalism.

Modernization of professional education involves integration of formal, non-formal and informal types to ensure a comprehensive educational process, reduce the volume of obligatory components and increase selective components of curricula and educational programs, modification of forms, methods, technologies and tools for mastering the content of disciplines at all levels of education, individualization and possibility of variable education systems. To this end, it is necessary to take measures to widely involve social partners, providers of formal, non-formal and informal education, as their integration is considered to be an important condition for comprehensive training of future specialists in hotel and restaurant industry.

Modernization is possible under the condition of: availability of highquality infrastructure of higher and postgraduate educational establishments, compliance with labor market demands and creation of adequate ways of further lifelong learning, flexible structure of professional education, measured by achievements in education, teaching and learning through school and professional education to higher and adult education, as well as recognition of results obtained in non-formal and informal education (competencies acquired in the workplace); creation of a pan-European educational space with transparent qualification systems and support for international mobility; increasing opportunities for international mobility of students and teachers in the field of professional education.

In conditions of innovative development of hotel and restaurant enterprises the need of systematic modernization of professional and practical training of future specialists in hotel and restaurant business is actualized, in particular concerning updating of training content, 
curricula of professional and practical training, revision of a ratio of theoretical and practical knowledge, abilities, skills, competencies in accordance with the needs of employers.

Innovation as a prognostic idea of business development and economy in the context of digitalization actualizes modernization of the educational process of training of future specialists in hotel and restaurant business through introduction of innovative technologies, including in the context of our research subject and personality-oriented technologies, problem-based and research learning, situational modeling and design. developmental learning, game and case technologies, collective and group learning, development of critical thinking, programmed, modular and interactive learning, motivation for success, etc. Innovation requires development of new forms of practical training of hotel and restaurant specialists through creation of educational and training programs, business incubators, selection of educational material to create cases; use of individual tasks, etc.

Along with higher educational establishments that train specialists for hotel and restaurant industry, public and professional associations play a significant role in modernization, among them Hospitality Industry Association of Ukraine, Association of Hotel Associations and Hotels of Ukrainian Cities, and All-Ukrainian Trade Union of tourism, spa and hotel industry workers, Club of hoteliers and restaurateurs HOTELIERO, NGO "Union of Rural Green Tourism of Ukraine", Union of Ukrainian Entrepreneurs, Public Union "Ukrainian Restaurant Association", business associations and others, as well as customers of educational services .

Analysis of information on the sites of the above professional public institutions makes it possible to understand their impact on training of specialists for service sector, because, in addition to interesting discussions of professional topics, problem view and solving, acquaintance with the best foreign and domestic experience, they contain training courses with the opportunity to get a certificate from a provider of non-formal education, which can be credited as a part (module) of a course of a certain discipline of the educational-professional specialist training program, stratification and specification of future activities, early narrow professionalization and gaining initial special experience. We find it especially valuable to provide trainings to get knowledge, practical skills and experience directly from successful Ukrainian and world entrepreneurs, which, in our opinion, will promote the development of small and medium business in service sector, promote non-standard thinking and future students' creative activities. 
Therefore, today in the service sector there is a wide range of nongovernmental organizations, trade unions, communities, vision, mission, tasks and areas of which are different, but their activities contribute to the promotion and practical training of specialists in hotel and restaurant industry.

Development of media education system in Ukraine, aimed at creating the foundation of state's humanitarian security, formation and cohesion of civil society, preparation of children, pupils, students for safe and effective interaction with the latest media system, formation of media information literacy and media culture according to age, individual and other personal characteristic, is another area of modernization of training of future specialists in hotel and restaurant business. The analysis of scientific and pedagogical literature allows to define basic directions of scientific researches of process of training of future specialists by means of media education, namely: formation of professional competence of future culturologists by means of digital technologies.

Examining the peculiarities of the use of means of media education in the training of future specialists in hotel and restaurant business, we note that the result of this educational and cognitive activity in general is identified with media information literacy, person's media immunity, personal reflection and critical thinking, ability to media creativity, specialized aspects of students' media culture.

The above process is carried out taking into account the specifics of media education principles, namely: personal socio-psychological approach, permanent updating of content, focus on continuous development of information and communication technologies in education, science and innovation, priority of moral and ethical personal values, respect for national traditions, aesthetics enthusiasm and productive motivation of students.

Professional training of future specialists in hotel and restaurant business by means of media education is carried out by watching educational and entertainment programs, feature, informational and educational films on TV channels, listening to podcasts in the radio space, creating and operating an attractive and interesting product, with a focus on students' abilities.

Let's dwell in more detail on a brief description of some of them. Thus, the use of records of MasterChef project programs (STB channel) is widely used in the educational process of training of future specialists in hotel and restaurant business, in particular while mastering disciplines "Technology of restaurant products", "Fundamentals of culinary arts", 
"Hygiene and sanitation in the branch". This program is the Ukrainian version of the British format, which provides an opportunity to witness culinary battles between chefs through the performance of competitions and tasks and it gives an opportunity to analyze their compliance with the requirements for cooking technology, as well as hygiene and sanitation during this process.

No less interesting and entertaining and at the same time educational, practical and informative, in our opinion, is the morning show with a maximum of relevant, useful and entertaining information "Breakfast with $1+1$ ". In addition to fulfilling the requirements for quality and proper cooking, the experience of presenting dishes, evaluations by the hosts, etc. is also instructive. No less popular and in demand among both viewers and students is "Culinary Show", in particular because of the length of the presented programs, which allows to use program records during mastering various modules of the above disciplines: "Eat for 100", "King of desserts", "Healthy eating", "Breakfast. Weekend", "Food in a big city", "Breakfast rules: Ruslan Senichkin's recipes".

Learning disciplines "Organization of restaurant business", "Commodity science and quality control of food", "Hygiene and sanitation in the branch" it will be important for the practical application of theoretical material to view and discuss recordings of reality shows "On knives", in which the presenter Olga Freimut with the help of wellknown experts, professionals, including restaurateur Dima Borisov, turns abandoned restaurants into successful places through a full analysis of work of the institutions: from kitchen and interior, to relationships in teams, identifies problems and helps to solve them in relations between employees, overcoming conflicts within teams, which are usually the main factor influencing business success.

We also consider the use of the TV program "The Best Restaurant with Ruslan Senichkin" to be cognitively interesting and practically in demand. This is a reality show for a wide community of consumers of restaurant services in Ukraine, in which representatives of restaurants from all over the country compete for recognition of their restaurant to be the best, evaluating competitors on four criteria: restaurant concept, service, cuisine and cleanliness.

An interesting task may be to write an essay on one of the topics of the electronic publication "The Village Ukraine", in particular, the section "Food" on the topics: "Live music, Georgian cuisine and dishes from the Hosper oven in the renovated Dediko restaurant", "25 establishments opened in Kyiv during the April lockdown", "These are the people who worked in restaurants in London and Shanghai, but 
decided to return to Ukraine", "For the gastronomic symbol of Kyiv Kyiv Pie chose a logo. And here's an alternative from YOD Group", "There are more than five of them: stories about tastes that evoke strong emotions", etc.

In the process of mastering the discipline "International Quality Standards of Hotel and Restaurant Business", it is advisable, in our opinion, to selectively review the programs of the TV show "Eagle \& Tail". The Ukrainian travel show tells about hotels and restaurants available for accommodation and food both for budgetary traveler and capable to pay for the highest-quality services. Getting acquainted with uniqueness of ethnic cuisine of the world, the hosts also inform about the cheapest and most expensive hotels, characterize them in terms of quality of service, comfort of living conditions, design features and etc. This material is useful when studying the topics of comparative studies of the hotel and restaurant business and comparison with similar Ukrainian institutions.

The use of podcasts (one or a number of digital media files of the oral genre, a means of distribution by synchronizing of radio shows, sound performances, interviews, lectures, etc. on players, personal computers) is also interesting at the current stage of development of education. During professional training of future specialists in hotel and restaurant business, we consider it appropriate to use the material presented on the platform "NV Podcasts", created with the support of the Press, Education and Culture Department of the US Embassy in Ukraine. Such professional and practical podcasts are meaningful: "What are you doing, Vasyl Grogol?" (Vasyl Grogol, founder of Bursa Hotel Kyiv, neobistro Supra, co-founder of coworking Kooperativ, talks about the role of the creative class in the society; new luxury and demand for it; difference between niche and network businesses and the trend of individualism; profitability of hotel and restaurant business and how it works in the United States and Europe, time management, family values and business partnership); "PeopleCast" (HR advisers and business people share experiences of their own business, performance and team building to transform attitudes towards employees, help in formation of productive culture and creation of your own dream-team based on the experience of the best companies and experts).

An important direction in the introduction of media in the educational process is use of culinary blogs on YouTube, Instagram, Facebook.

In particular, the material "Top 5 culinary blogs on YouTube - and the best recipes from the chefs" provides interesting, meaningful and practical information for laboratory classes, master classes on Gordon 
Ramsey (16.5 million subscribers), Jamie Oliver (5 million subscribers), John Mitsuich (3.8 million subscribers), Leon and Daniela Hoffman (80 thousand subscribers), Eugene Klopotenko (125 thousand subscribers).

For its part, the material "10 culinary blogs on Instagram for inspiration and learning" provides tags with selection of culinary blogs to learn how to cook your favorite restaurant dishes at home: Nando's (every Thursday, the chef of the Nando's restaurant chain gives master classes on cooking Portuguese-African cuisine); Wagamama (every Wednesday the chef of the Wagamama chain tells how to cook top Asian dishes), Bread Ahead (every day at 2 p.m. (London time) the British bakery school shares recipes for delicious pastries - from bread to cakes), Padella Pasta (one of London's best restaurants has joined the educational trend on Instagram and regularly publishes recipes of their best Italian dishes), Leon "(a culinary blog from the restaurant of "healthy fast food"), etc.

Facebook pages are also supporting material for the educational process. Interesting from this point of view are the following blogs "Culinary blog Tasty World. Simple recipes and interesting establishments", "Culinary blog from chef Oksana Vozniuk", "Culinary blog Tandicook", "Ukrainian Gastro Show", etc.

Due to the desire and ability of Ukrainian hotel and restaurant establishments to enter the world markets of services in the service sector and to promote ethnic cuisine, many companies are blogging. Attractive from this point of view is the material "10 Ukrainian food-blogs for culinary inspiration" from the site Korysno.pro, which, however, represents articles by ordinary users on the ancient and modern traditions of national cuisine.

Modern and effective in the process of professional training of future specialists in hotel and restaurant business is the creation of Smarttechnological space that provides access to international information systems for the organization of the educational process, broadens the mind, develops critical and creative thinking. Priority is given to developing skills of working with information, ability to apply modern innovative technologies in educational-cognitive and future professional activity.

The modern world is characterized by a state of constant global changes and breakthroughs in the development of information technology, which leads to the active introduction of interactive learning. Therefore, it is worth realizing the enormous opportunities introduced by new interactive and information technologies not only for the 
convenience of life, but also for use in all spheres of human activity and education, while learning to apply them competently.

"Smart-technologies" are hardware and software for using the advantages of the global information society in order to carry out joint educational activities on the Internet and provide educational services of a new quality. The word "Smart" has several meanings: it means "clever", expending of the abbreviation allows its specification as Self-directed, Motivated, Adaptive, Resource-enriched and Technology embedded. Smart education is the use of smartphones, tablets, interactive whiteboards, other devices with the Internet access, as well as various educational programs and applications for educational purposes. But it is more important to create an integrated intellectual virtual environment for learning with educational content that is developed and improved by all participants of the educational process.

The concept of Smart Education includes:

1. Creating an intellectual environment for the continuous development of competencies of participants in the educational process, including activities of formal and informal learning process, the result of which is a change in the demonstration of behavior through the application of new competencies acquired by them. The technical basis for the implementation of such education is the entire existing fleet of devices that belong to students and educational institutions: ordinary desktop computers, laptops, tablets, smartphones and more. The goal is to develop the skills needed to succeed in a digital society and smart economy.

The main characteristics of Smart Education:

1. Allows you to provide equal opportunities for learning, regardless of devices, ensuring the possibility of implementing the continuity of the learning process and integrity of educational information.

2. Ability to be independent of time and place, mobility, continuity and ease of access to educational information.

3. Autonomy of a teacher and a student through the use of mobile devices and access to educational information.

4. Evaluation of effectiveness of the educational process is measured not as the acquired knowledge, much as the ability to apply it in practice.

5. Flexible learning in terms of preferences and individual capabilities of the student (ability to adjust learning to the student's individual parameters, including such as: basic knowledge, experience 
and skills, learning style, and even physiological and psychological state at a particular moment of study).

FORBS magazine covered the latest educational trends that correlate with the concept of Smart Education. They are:

- video courses on Your Tube and iTunes are becoming not only mega-popular, but also in demand with the younger generation;

- personalization of learning is an alternative to unified approaches in education, which require the same results from all subjects of learning,

- individual psychological characteristics of an individual should become the basis for personal educational programs, the basis on which the motivation to learn will appear and students will receive a boost for development of intelligence, creativity and creativity;

- gamification (introduction of game technologies in non-game situations, virtual learning situations with an algorithm for their solution, simulation and structuring, web quests)

- interactive textbooks should radically change the "traditional" views and interpretation of educational material with technology (color photos, audio and video support, interactive infographics, etc);

- learning through video games is a unique opportunity to provide knowledge about the real world through an interactive immersion in the virtual world

- construction of multifunctional educational portals, creation of thematic blogs, own offices, Wiki-pages.

E-learning is based on the use of information and telecommunication technologies and covers the whole range of actions, from supporting the learning process to delivering educational content to learners. It is based on three main principles: work is carried out in a network; delivery of educational content to the end user is carried out with a computer using Internet technology

One of the advantages of the Smart Technology Space is that students can acquire knowledge using the global network in virtual interaction, mastering new sources of information and communication. The possibilities of using Smart-technologies are inexhaustible. Their use increases the level of motivation of students to study and attracts them to communicate in a foreign language with mother-tongue speakers.

Being in the Smart-space stimulates the development of mental activity by performing actions with the help of a dynamic image. Unlike traditional teaching methods, which are not so interesting and effective for modern youth, with the use of Smart-tools there is an opportunity for a teacher to present tasks of different complexity and type in an attractive format. Due to various programs, it is much easier to create a foreign 
language environment in which a student is immersed and adapted, studying values, customs, and social environment for successful foreign language communication. This allows to organize the process of training of specialists at a qualitatively new level.

Using flexible tools of modern technologies, students can conduct modeling of various phenomena, group research on a large-scale problem, have an opportunity to share the results quickly. All these factors significantly accelerate the development of foreign language culture.

Significant advantages of working in a single virtual environment is also an opportunity to organize and adjust work of a group of students on a single project. Smart-technologies allow to significantly accelerate the teacher's control over the process and result of students' work, simplify the diagnosis of upbringing of a foreign language communication culture.

Using a single system of personal classrooms of the educational platform, a teacher can organize distance learning, while maximally individualizing the process for each student, giving him an opportunity to perform specially selected tasks or receive blocks of structured learning material. This creates a personalized integrated educational Smartenvironment.

Transformation of Smart-environment into educational and developmental space is purposefully realized as the organization of activities of students in the most favorable conditions for personal development, that removes fear of possible failure, encourages efforts to succeed, initiates activity, creativity, self-confidence, achieving positive results.

From scientists' prospective E-Learning is realized using the principles of: diversification (diversity and variability of forms, content of training of specialists); personality-oriented approach (requests, needs, individual level of future specialists); optimality (optimality of content, forms, methods of training); openness and accessibility (voluntary participation and freedom of choice of program and educational trajectory).

The complex approach of resource-oriented training of professional disciplines of professional training of future specialists in hotel and restaurant business consists in integrated use of classrooms, offices, laboratories with the corresponding specialized equipment, modern subject-spatial environment for application of the newest educational technologies, modern technical training resources: multimedia projectors, screens, laptops, etc. Technical characteristics of machinery 
and equipment correspond to the methods, techniques and technologies that must be mastered by students of higher educational establishments to use them practically (organoleptic, technical and economic calculations, restaurant technology, service technology, use of modern information technology, etc).

Particular attention should be paid to cooperation with the hotel and restaurant industry of the region to improve professional training of students of higher educational establishments, connected with the use of material and technical base of partner institutions for practical, laboratory classes, training and production practices, internships. E-Learning also provides for adequate staffing: academic staff has the right to choose basic teaching methods (lectures (interactive, guest, binary, lecturepresentations), multimedia presentations, test tasks, oral discussions in the form of debates at practical classes, preparation of notes (bullet points, reports), explanations, story, creative, situational and research tasks, trainings, seminars and master classes from famous restaurateurs, chefs and hoteliers, educational trips, practical training in production, in virtual laboratories, training with hotel management on virtual business process simulators NOTS, meetings for networking and career coaching from practitioners, business representatives, experts and scientists, opinion leaders, scientific seminars, etc.

The use of smart technologies makes it mandatory to provide students with the necessary training materials through transmission of video, audio, text and graphic information in synchronous or asynchronous mode, online and offline communication during distance learning.

Teaching and learning methods during distance learning and the use of smart education include demonstration, creative and problem-solving methods, educational discussion and / or debate, brainstorming, case study / situation analysis, etc. The educational process is carried out using teaching and learning technology: problem lectures (problem solving), visualization lectures (video demonstrations, etc), binary lectures (two lecturers - a teacher and a practitioner), lectures with preplanned mistakes, lectures - press conferences, search laboratory work, research work, heuristic conversation, role and business games, educational games, trainings in active mode, analysis of specific situations Case study, solution of inventive tasks, analysis of business correspondence, etc.

In addition to the resources of university libraries, funds of faculties, chairs, trtaining of students is carried out through the use of online communication and digital interaction: sites, blogs, forums, chats, dialogues or correspondence, conferences using traditional means of 
Internet communication: Skype, Facebook , Messenger, Telegram, Viber, YouTube, Google-class, various platforms, including the KSU online platform, as well as Zoom.us, Cisco Webex Meetings, Google Classroom, Moodle, Kahoot, Microsoft Teams, Discord, etc. We consider the use of Internet resources of social networks: Instagram, Facebook, LinkedIn, Snapchat, Tumblr, Twitter, Pinterest, WhatsApp, etc. to be rational in the process of professional training of future specialists in hotel and restaurant business. Thus, Creativity.ua initiated film viewing for development of creative and critical thinking, as if you search in a huge information space you will have to fight for the attention of service consumers, and this will contribute to the ability to be unconventional, realising bright and unusual ideas. The following films are offered for viewing: "Tail Twists the Dog" (1997), "Where Dreams Lead" (1998), "Syrup" (2011), "Interns" (2013), "Intern" (2015). In addition, we consider it relevant to watch professionally-oriented films: "Enjoy your meal" (2010), "Chef " (2012), "Spices and Passions" (2014), "Cook on Wheels" (2014), "Chef Adam Jones" (2015), "Noma - My Perfect Storm" (2015). Blogs are also important as a type of a website, the main content of which is recordings, images or multimedia that are regularly added. Here are examples of similar blogs: Gastronomic blog "Kharch", Gastrofamily, Blog of the Home deli, Gastronomic restaurant, Lviv gastronomic, The best gastronomic festivals of Ukraine, Time to eat, etc.

The use of network applications intensifies the possibilities of elearning for organization of the educational process connected with searching the network for information, production and improvement of digital resources, which include hypertexts, hypermedia content, own sites, online mind maps, etc.), participation in network communities (educational, social, professional, scientific, etc.). For effective organization of e-learning, one of the forms of which is distance learning, the following services are of interest: sites, blogs (a tool for publishing materials online with access to reading, keeping a personal diary online); wiki (a tool for creating a collective hypertext in which the history of changes is saved); YouTube (video hosting for storing, viewing and discussing digital videos). Mindmapping, or so-called "Tony Busen mind maps" is rather interesting,it is a service for reproducing general system thinking with mental maps, e.g, Google Drive, online application Miro, Bubbls.Us, Coggle, Mindmeister, Mindomo, etc.); virtual classes (e.g. Google Classroom, LearningApps); virtual boards (e.g. Padlet, Linoit, Trello); full-fledged distance courses on various online platforms, 
so-called learning management systems; services for video conferencing, webinars (e,g. ZOOM Cloud Meetings), etc.

The preliminary analysis made it possible to determine the factors for improving professional training of future specialists in the hotel and restaurant business, among which are:

- development of bases of professional and practical training of students (regardless of the profile of the educational establishment, forms of ownership) through improvement of bases of practices, operation of innovative enterprises, strengthening of social partnership, etc;

- brining practitioners among authoritative (successful) workers of service sector, in particular hotel and restaurant business, into teaching of professional disciplines;

- formation of connections of pre-higher and higher professional education with the labor market and strengthening the role of enterprises, organizations, institutions in providing jobs for professional and practical training of students;

- development of modern technologies of professional and practical training, development of professional and perspective standards of training, curricula of professional education on the basis of competence, modularity and educational results;

- improving the quality of teaching and management staff through training and international internships, participation in the implementation of European Union programs that support projects of cooperation, partnership, activities and mobility in the field of education, professional training, youth and sports;

- preparation and publication of professional textbooks, training manuals, guidelines, glossaries for learning specialized disciplines with participation of practitioners, taking into account the latest changes and requirements of the digital society for professionals;

- increasing opportunities for students-future specialists in hotel and restaurant business to access the experience of studying at leading universities in European countries;

- holding specialized contents, competitions in hotel and restaurant business, other types of motivative actions with various practical incentives;

- improving the mechanism of employment of graduates, providing the best nominal scholarships, grants, opportunities for internships with further employment in the best (successful) structures of the hotel and restaurant business; 
- regular monitoring and analysis of the results of the educational process and further employment, public implementation of changes and regular coverage of these processes.

\section{CONCLUSIONS}

Thus, global and Ukrainian development of hotel and restaurant business as a component of a service sector and scientific knowledge puts before future specialists the requirements of appropriate training, competitiveness and professional mobility in the service sector, which also provides continuous professional development, internships and lifelong learning.

Analysis of Ukrainian practice of training of future specialists in hotel and restaurant business, taking into account today's requirements, demands of customers of educational services (stakeholders, applicants, society) remains a question, that needs modernization and practical implementation in higher educational establishments.

Modernization of professional training of future specialists in hotel and restaurant business has to provide an integrated educational process, update curricula, educational and professional programs, modify forms, methods, technologies and tools, individualize different education systems, increase international mobility for teachers and students. It is performed if available appropriate material and technical base of educational institutions, enterprises-bases of practices, compliance with the demands of the labor market, flexible structure of professionakl education, integration of formal, non-formal and informal education; creation of a pan-European educational space with transparent qualification systems and support for international mobility; increasing opportunities for mobility of students and teachers of professional education.

\section{SUMMARY}

Based on the results of theoretical and methodological analysis of the experience of professional training of future specialists in hotel and restaurant business, as well as the processes of modernization of professional training of future specialists in hotel and restaurant business, the state and problems of professional training of specialists in hotel and restaurant business are outlined. The author's definition of the concepts "professional training of future specialists in hotel and restaurant business", "specialist in hotel and restaurant business", "competence of future specialists in hotel and restaurant business", "readiness of future specialist in hotel and restaurant business for professional activity" is formulated. Necessity of wide involvement of social partners, providers of 
formal, non-formal and informal professional education in cooperation is substantiated. Domestic experience of modernization of professional training of specialists in hotel and restaurant business taking into account dynamic changes in the field of professional education is considered. The sites of non-governmental public organizations, trade unions, communities on the availability of educational and cognitive information in order to help improve the educational process are analyzed. Importance of using elearning, in particular information and communication technologies, media education, Smart-technologies, etc., during the professional training of future specialists in hotel and restaurant business for laying the foundation of successful professional activity, professional career, realization of the concept of life success is determined.

\section{References}

1. Бабешко М.С. Універсальна модель професійної підготовки майбутніх фахівців готельно-ресторанної індустрії. Педагогіка формування творчої особистості у вищій $i$ загальноосвітній школах. 2017. Вип. 53 (106). С. 63-70.

2. Бурак В.Г. Модернізація професійної підготовки фахівців готельно-ресторанного господарства. Нова педагогічна думка. 2020. № 4 (104). C. 7-12.

3. Бурак В.Г. Концептуальні основи професійної підготовки майбутніх фахівців готельно-ресторанної справи в закладах вищої освіти. Актуальні питання гуманітарних наук. 2021. № 37. С. 202-209.

4. Бурак В.Г. Специфіка формування компетентності фахівців готельно-ресторанної справи в процесі професійної підготовки в закладах вищої освіти. Нова педагогічна думка. 2021. № 2 (106). C. $32-38$.

5. Бурак В.Г. Професійна підготовка майбутніх фахівців готельно-ресторанної справи в контексті реформи освіти та науки. Вісник Польсько-української науково-дослідної лабораторії дидактики імені Я. А. Коменського. Вип. 2(22): Сучасні проблеми обдарованості особистості: II Міжнар. наук.-практ. конф. (Умань, 20-21 травня 2021). Умань, 2021. С. 28-32.

6. Бурак В.Г. Смарт-технології в професійній підготовці майбутніх фахівців готельно-ресторанної справи. Сучасні напрями розвитку педагогіки та педагогічної психологї̈; актуальні питання філології та мовознавства: II Міжнар. спеціаліз. наук. конф. (ІваноФранківськ, 11 червня 2021). Івано-Франківськ, 2021. С. 83-86.

7. Віндюк А.В. Особливості практико-орієнтованого змісту професійної підготовки майбутніх фахівців із туризмознавства в 
закладах вищої освіти. Вісник Запорізького національного університету. Педагогічні науки. 2017. № 2. С. 98-103.

8. Динаміка освітніх процесів та підготовка майбутніх фахівців у системі вищої освіти: відповідь на сучасні суспільні запити : колективна монографія / Ю. Д. Заячук та ін. Львів : ЛНУ імені Івана Франка, 2020. 250 с.

9. Зінченко В.А. Особливості підготовки кадрів туризму i готельної справи в умовах євроінтеграції України та підвищення конкурентності туристичної галузі. Проблеми освіти. 2017. Вип. III (67). С. 241-259.

10.Колот А., Герасименко О. Сфера праці в умовах глобальної соціоекономічної реальності 2020: виклики для України. URL: http://library.fes.de/pdf-files/bueros/ukraine/16344.pdf

11.Короткова Л.І. Структура педагогічної системи професійної підготовки майбутніх фахівців сфери послуг в умовах освітньовиробничого кластера. Colloquium-journal. 2020. № 25 (77). URL: https://cyberleninka.ru/article/n/struktura-pedagogichnoyi-sistemiprofesiynoyi-pidgotovki-maybutnih-fahivtsiv-sferi-poslug-v-umovahosvitno-virobnichogo-klastera.

12.Кудла Н.С., Мандро Х.М., Мошура Д.А. Ринкові вимоги до підготовки фахівців готельно-ресторанної сфери. Інновації, тренди та перспективи індустрії гостинності: матеріали I Міжнародної науково-практичної конференції (м. Львів, 12 грудня 2019 р.). Львів: ЛТЕУ, 2019. 192 с. С. 135-138.

13.Маринюк А.Ю. Основні аспекти професійної підготовки майбутніх фахівців галузі гостинності на сучасному етапі. Економічні горизонти. 2017. № 2 (3). С. 80-84.

14.Плахотнік О.В., Слюсаренко Н.В. Тенденції удосконалення професійної підготовки фахівців вищої школи. Педагогічний альманах. 2016. Вип. 29. С. 87-96.

15. Поночовна-Рисак Т. М. Проблеми професійної підготовки майбутніх фахівців готельно-ресторанної справи. Педагогіка формування творчої особистості у вищій $i$ загальноосвітній школах. 2019. № 62. Т. 1. С. 66-69.

16.Радкевич В.О., Кравець С.Г., Козак А.Р. Ключові компетентності (м'які навички) майбутніх фахівців індустрії гостинності. Colloquium-journal. 2020. № 15 (67). URL: https://cyberleninka.ru/article/n/klyuchovi-kompetentnosti-m-yakinavichki-maybutnih-fahivtsiv-industriyi-gostinnosti. 
17.Савченко Л. Зміст професійної підготовки фахівців сфери обслуговування. Професіоналізм педагога: теоретичні й методичні аспекти. 2019. Вип. 11. С. 72-80.

18. Слюсаренко Н., Кульбацька М. Суб’єкт-суб'єктний підхід до організації педагогічного процесу. Людинознавчі студіï. Педагогіка. 2015. № 1 (33). C. 194-201.

19.Сопіга В.Б., Сорока Т.П. Тенденції розвитку готельноресторанних підприємств як фактор впливу на підготовку майбутніх фахівців сфери обслуговування. Вісник КрНУ імені Михайла Остроградського. 2019. Вип. 2 (115). С. 36-41.

20. Чуєва І.О., Криволапов Е.А. Шляхи підвищення конкурентоспроможності майбутніх фахівців готельно-ресторанної справи методами перехресного навчання. Педагогіка формування творчої особистості у вищій $і$ загальноосвітній школах. 2019. № 63. Т. 2. C. 206-210.

21.Burak V. Training of future specialists in hotel and restaurant industry in higher educational establishments in the conditions of distance learning. ScienceRise: Pedagogical Education. 2020. № 6 (39). P. 16-20.

22. Kashyna G., Nazarova K., Burak V. Development of scientific and natural competence of technology teachers in the system of postgraduate education by means of information and communication support. EdukacjaTechnika-Informatyka. 2019. № 4 (30). P. 151-155.

23. Khomova O., Yanchycka K., Shkatula O., Burak V., Frolova O. Trends in the development of tertiary education in the context of modern challenges. Applied Linguistics Research Journal. 2021. № 5 (4). P. 126-133.

24. Savina N.B., Slyusarenko N.V., Yakobchuk M.S., Gromaszek K., Smailova S., Muslimov K. Using of entropy at estimation business risks. International Journal of Electronics and Telecommunications. 2021. № 2 (67). P. 169-174.

25.2017 U.S. Conference of Mayors Tourism, Hotel and Lodging Survey Executive Summary. AHLA. 2017. URL: https://www.ahla.com/ sites/default/files/AHLA_USCM_ExecSummary\%20latest.pdf

Information about the author: Burak Valentyna Hennadiivna,

Candidate of Technical Sciences, Associate Professor at the Department of hotel-restaurant and tourist business Kherson State University 27, University St., Kherson, 73003, Ukraine 